\title{
Protective Immunity of Single and Multi-antigen DNA Vaccines against Schistosomiasis
}

\author{
E Nascimento, IC Leão*, VRA Pereira, YM Gomes, P Chikhlikar*, T August*, E Marques*, \\ N Lucena-Silva/ ${ }^{+}$
}

\begin{abstract}
Departamento de Imunologia, Centro de Pesquisas Aggeu Magalhães-Fiocruz, Av. Moraes Rego s/nº, Campus da UFPE, Cidade Universitária, 50670-420 Recife, PE, Brasil *Johns Hopkins University, School of Medicine, Baltimore, MD, USA
\end{abstract}

We evaluated the usefulness of the combination of three plasmids encoding tegumental (pECL and pSM14) and muscular (pIRV5) antigens of the Schistosoma mansoni on improving the protective immunity over the use of a single antigen as DNA vaccines. Female BALB/c mice were inoculated twice with $25 \mu \mathrm{g}$ DNA plasmid within two weeks interval. The challenge was performed with 80 cercarias of a regional isolate of $\mathrm{S}$. mansoni (SLM) one week after the last immunization. Six weeks after challenge, all mice were perfused for worm load determination. The following groups were analyzed: saline; empty vector; monovalent formulations of pECL; $P S M 14$ and pIRV5 and also double combinations of pECL/pIRV5 and pIRV5/pSM14 and a triple combination of pECL/pIRV5/pSM14. The protection was expressed as a percentage of worm loads in each group compared with the saline group. The results obtained were $41 \%(p<0.05)$; $52 \%(p<0.05) ; 51 \%(p<0.05) ; 48 \%(p<0.05) ; 55 \%(p<0.05) ; 45 \%(p<0.05)$; $65 \%(p<0.05)$ for each group respectively.

Key words: naked-DNA - DNA-vaccine - schistosomiasis - Schistosoma - multivalent - SM14 - IrV5 - ECL

Schistosomiasis is an important public health problem affecting more than 200 million people in tropical and subtropical countries around the world (El-Garem 1998). In Brazil, the endemic area covers two third of the east coast, from Rio Grande do Norte to Minas Gerais, with the states of Paraíba, Pernambuco and Alagoas having the highest prevalences (Ximenes et al. 2000). The Nacional Health Foundation (Funasa) estimated that there are approximately 3 million people infected in the endemic areas of Brazil. The main strategies for control of schitosomiasis have relied on the use of mulusccides and treatment of the infected people. Despite the effectiveness of this strategy on reducing the disease prevalence and the severity of the clinical symptoms, its high cost is a problem for developing countries to maintain these control programs for long periods (Chitsulo et al. 2000). Another approach considered is the development of antischistomiasis vaccines, designed to be given during childhood, however no such vaccine is available yet.

Attenuated vaccines based on radiated cercariae has demonstrated protection of mice and non-human primates from schistosome challenge, however its use in humans is not considered safe (Coulson 1997, Wilson \& Coulson 1998).

The DNA vaccines can induce both the humoral and cellular arms of immune system (Kallina 1997). The immune protection conferred by nucleic acid based vaccines

This work was founded by Brazilian Research Council (CNPq), PADCTIII/CNPq no. 620470/98-4, Fiocruz and TDR no. 991020.

${ }^{+}$Corresponding author Fax: +55-81-3453-2449. E-mail: nlucena@cpqam.fiocruz.br

Received 18 June 2002

Accepted 15 August 2002 has been studied in different animal model and for different parasites, such as, Schistosoma (Mohamed et al. 1998), Plasmodium (Grifantini et al. 1998), Leishmania (Xu et al. 1995) and Mycobacterium (Morris et al. 2000); virus, as rabies (Lodmell et al. 1998), herpes (Sin et al. 2000), hepatitis C (Arichi et al. 2000), influenza (Dégano et al. 2000, Johnson et al. 2000), dengue (Raviprakash et al. 2000), measles (Schlereth et al. 2000), cytomegalovirus (Morello et al. 2000); as well as for melanoma (Xiang et al. 2000), and immune diseases, such as encefalomielitis (Weissert et al. 2000).

It is postulated that an antigen candidate for vaccine development against schitosomiasis should give consistently at least $40 \%$ of protection. We are evaluating the immune protection level of three antigens Sm14, ECL and IrV5, individually and in combinations of DNA vaccines against schistosomiasis.

\section{MATERIALS AND METHODS}

Preparation of DNA vaccines - Three DNA vaccine constructions were used: pECL codes for the $200 \mathrm{kDa}$ glycosylphosphatidylinositol-anchored surface protein involved on the immune response to praziquantel treatment (Sauma et al. 1991); pSm14 codes another tegumental protein involved on the transport of fatty acids (Tendler et al. 1996); and pIrV5 (Soisson et al. 1992, 1993, Soisson $\&$ Strand 1993) codes for a $62 \mathrm{kDa}$ muscle protein. All constructions were obtained from an overnight batch fermentation of the plasmid recombinant harboring Escherichia coli DH5 $\alpha$ strains. Plasmid DNA was extracted and purified with the Flexiprep DNA-extraction Kit from Pharmacia in endotoxin-free conditions and was sterilized with $70 \%$ ethanol wash.

Vaccination of mice - Six weeks old female BALB/c mice were divided into groups and inoculated subcutaneously with $50 \mu \mathrm{l}$ of naked-DNA $(0.5 \mu \mathrm{g} / \mathrm{ml})$ saline solution in two doses within 15 days interval. Vaccination was per- 
formed with each plasmid, pECL, pSm14 or pIrV5 and combinations of two or three of these. One week after immunization the animals were challenged with 80 cercariae from the São Lourenço da Mata strain (SLM), a regional strain, and six weeks after challenge each mice group was perfused with saline for harvesting the worms. Protection was expressed as a percentage of the worm burden in each vaccinated group compared to the saline inoculated group. Each experiment was performed at least twice.

Enzyme-linked immunosorbent assay - Blood samples were collected from each animal by retro orbital punction before each vaccination event, challenge and perfusion. A pool of serum was prepared from samples collected in each group and tested for reactivity with SWAP (soluble worm antigen preparation). A 96-well plates (Nunc) were coated with $100 \mu \mathrm{l}$ per well of SWAP $(10 \mu \mathrm{g} / \mathrm{ml})$ overnight at $4^{\circ} \mathrm{C}$. The plates were washed with PBS pH 7.4 containing $0.05 \%$ tween 20 (PBS-Tween) and blocked with a $2 \%$ bovine serum albumin in PBS-Tween for $4 \mathrm{~h}$ at room temperature. The wells were incubated with $100 \mu \mathrm{l}$ of a serum pool from each animal experimental group at 1:20 dilution in triplicates and incubated overnight at $4^{\circ} \mathrm{C}$. After washing six times with PBS-Tween 20 buffer, the plates were incubated $1 \mathrm{~h}$ with $100 \mu \mathrm{l}$ of the biotinylated anti-mouse imunoglobulins $(0.5 \mathrm{mg} / \mathrm{ml}$, Pharmigen $)$ and washed prior incubation with peroxidase-labelled streptavidin for another $1 \mathrm{~h}$ at room temperature. Colour development was initiated by the addition of DAB substrate and stopped with $2 \mathrm{~N}$ sulfuric acid solution. The reaction was measured at $40 \mathrm{~nm}$ in an ELISA Reader (BioRad).

Statistic analysis - The variance of the worm burden between the control group and each sample group was first calculated by the F-Test and then submitted to the Student Test. The protection was significant when $\mathrm{p}<0.05$.

\section{RESULTS}

The induction of protective immunity by a single schistosomose antigen encoded-DNA vaccine - Four groups of BALB/c female mice were vaccinated with $25 \mu \mathrm{g}$ of total DNA. One group received the empty vector (pVAX) while the other three groups received a combination of equal amounts of pVAX and a plasmid encoding one of the antigens, pECL, pSm14 or pIrV5. An additional fifth group was inoculated with saline as control for the challenge. The results is shown in the Table. The group inoculated with the empty vector induced an non-specific immune response leading to an important reduction (41\%) of worm burden after challenge in relation to one inoculated with saline. Those groups which received Schistosoma antigen encoding plasmid in combination with the expression vector gave a higher protection level comparing to the saline group. The reduction of parasitic load for the following groups: pVAX + pECL , pVAX + Sm14 and pVAX + IrV5 were $52 \%, 51 \%$ and $48 \%$, respectively .

The induction of protective immunity by a double Schistosoma antigen encoded-DNA vaccine - In order to investigate the effects of multiple antigens combinations on protection, we performed an experiment mixing equal amounts of plasmids encoding different schistosome antigens. Four groups of ten female BALB/c mice were vaccinated as described in materials and methods with $25 \mu \mathrm{g}$ of total DNA with combinations of two plasmids and a triple formulation of $8 \mu \mathrm{g}$ of each plasmid. The reduction of worm burden with the double formulations $\mathrm{pECL}$ and pIrV5, pSm14 and pIrV5, were respectively 55\% and 45\% which did not represent improvement over the single formulation using this schedule protocol for vaccination. Nevertheless, the triple fomulation gave the highest level of protection, $65 \%$ ( $\mathrm{p}<0.0001)$ (Table).

Serological reactivity against SWAP upon immunization and challenge - Samples were collected two weeks after the first vaccination and after the challenge. Serum of each mice within each experimental group was polled tested for reactivity against SWAP. Monovalent DNAvaccines examined showed a similar absorbance values for IgM and $\operatorname{IgG}$ detection before challenge, while the double vaccine formulation showed a tendency for $\operatorname{IgG}$ predominance either after vaccination (Fig. 1A) or challenge (Fig. 1B). The degree of stimulation of the specific humoral response to the vaccination was two times higher after challenge.

\section{DISCUSSION}

The development of vaccines for complex parasites, such as Schistosoma, is a great challenge. A DNA vaccine encoding the $20.8 \mathrm{kDa} S$. mansoni tegumental protein tested against an experimental murine schistosomiasis induced 30\% of protection (Mohamed et al. 1998). In

TABLE

Analysis of worm burden in vaccinated mice

\begin{tabular}{|c|c|c|c|c|c|}
\hline Groups (n) & $\begin{array}{c}\text { Weight } \\
\text { average }(\mathrm{g})\end{array}$ & $\begin{array}{c}\text { Sex } \\
(M+F)\end{array}$ & $\begin{array}{l}\text { Worm average } \\
\text { (SD) }\end{array}$ & $\begin{array}{c}\text { Protection } \\
(\%)\end{array}$ & $\mathrm{p}$ \\
\hline Saline (7) & 15.5 & $159+140$ & $42.7(2.9)$ & - & \\
\hline Empty vector (EV) (7) & 15.0 & $95+81$ & $25.1(6.3)$ & 41 & $9 \mathrm{E} 05$ \\
\hline pECL + EV (7) & 17.2 & $59+83$ & $20.3(2.9)$ & 52 & 7 E09 \\
\hline pSm14 + EV (7) & 14.5 & $104+84$ & $20.9(6.7)$ & 51 & $1 \mathrm{E} 06$ \\
\hline pIrV5 + EV (8) & 14.9 & $94+83$ & $22.1(9.1)$ & 48 & $1 \mathrm{E} 04$ \\
\hline Saline (7) & 12.9 & $104+59$ & $23.2(3.5)$ & - & \\
\hline pECL + pIrV5 (6) & 14.5 & $36+27$ & $10.5(4.0)$ & 55 & $6 \mathrm{E} 05$ \\
\hline pSm14 + pIrV5 (8) & 13.1 & $57+46$ & $12.8(5.6)$ & 45 & $1 \mathrm{E} 03$ \\
\hline pECL + pIrV5 + pSm14 (9) & 11.6 & $38+35$ & $8.1(3.7)$ & 65 & $6 \mathrm{E} 03$ \\
\hline
\end{tabular}



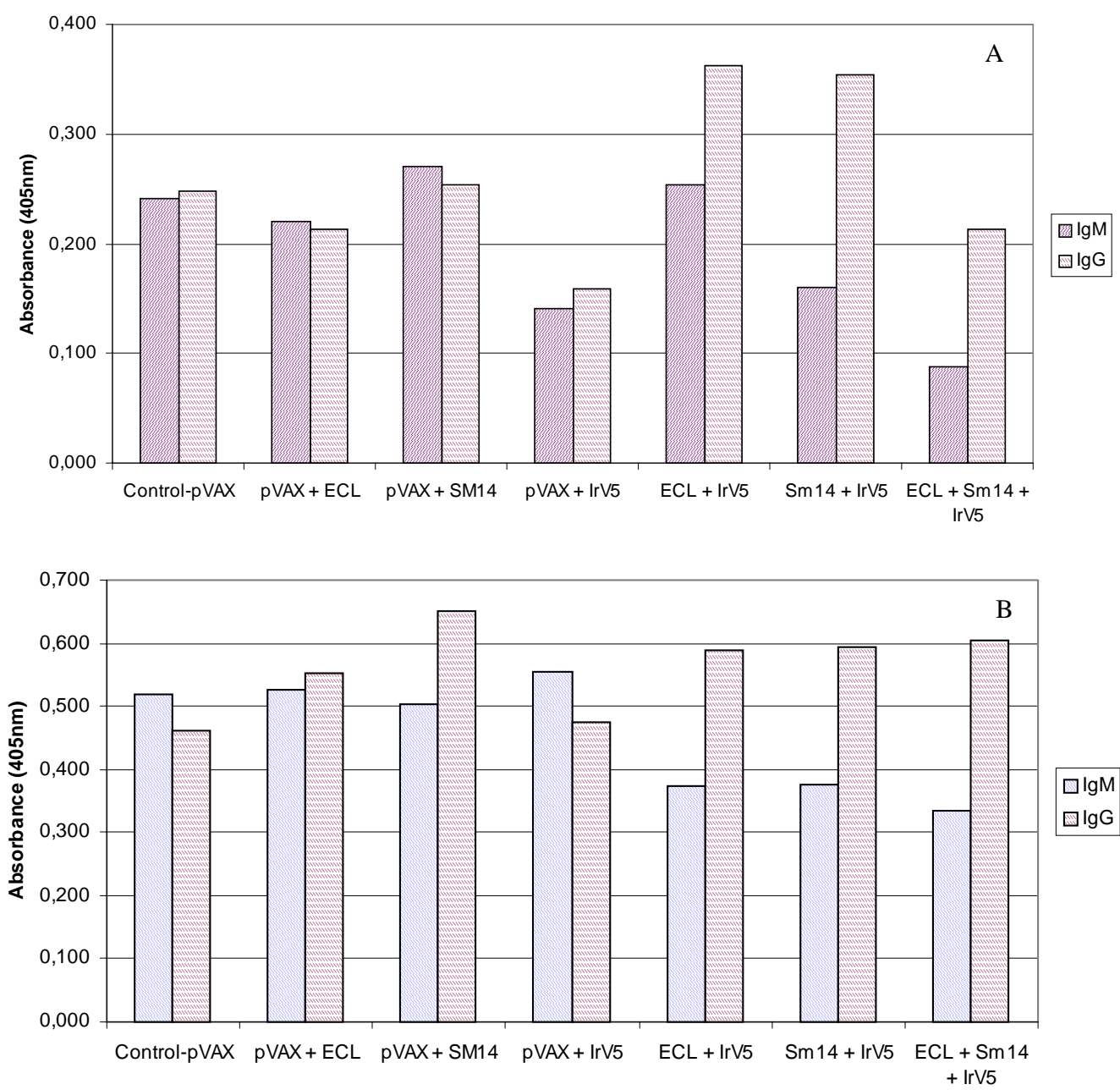

Fig. 1: specific IgM and $\operatorname{IgG}$ antibody response to soluble worm antigens two weeks after the first immunization (A) and after challenger (B). Each bar represents the optical density value of a pool of animal serum from each experimental group, as displayed on the legend.

another example, DNA immunizations of C57B1/6 mice with pWR6mutP8, which codes for a mutant form of S. mansoni calpain (Hota-Mitchell et al. 1999) provided of 60\% protective immunity, which was correlated to the production of antigen specific IgG1 (Th2 response).

Several DNA-vaccine constructions encoding for $S$. japonicum paramiosine did not induce protective immunity after challenge, despite inducing the production of specific antibodies $\operatorname{IgG} 1, \operatorname{IgG} 2 \mathrm{a}$ and $\mathrm{IgG} 2 \mathrm{~b}$ (Waine et al. 1997). Serological reactivity for IgG was also observed after DNA immunizations of the $23 \mathrm{kDa}$ tegumental protein albeit no protection was detected after challenge (Waine et al. 1999a). The comparison of the genetic immunization with a plasmid coding either a secreted or nonsecreted form of S. japonicum $22 \mathrm{kDa}$ tegumental protein demonstrated the influence of the plasmid construction on the capability to induce specific IgG response, being superior in animals inoculated with the secreted form, however neither group induced protection to challenge (Waine et al. 1999b). The same happened to the DNA vaccine expressing Sj62 (Zhang et al. 2000), a homolog of the S. mansoni IrV5 sequence. Chlichlia et al. (2002) showed that the S. mansoni (Sm32) asparagil endopeptidase DNA vaccine induced a specific humoral response, however, despite no reduction on worm load was observed in challenge experiments, there was a reduction on parasite fecundity resulting on the gain of weight by the vaccinated animals. DNA vaccine coding $S$. japonicum glutation-S-transferase (SjpGST28) was studied using different immunization protocols in different mice strains, but no antibody or protection after challenge was detected (Scott \& McManus 2000).

We now present that the three DNA encoded $S$. mansoni antigens Sm14, IrV5 and ECL induced protective immunity ranging from 45 to $55 \%$ in a individually or in combinations of two. The important non-specific protection induced by the empty vector probably is due to the short vaccination schedule used and perhaps induced by the $\mathrm{CpG}$ motifs on the backbone of the plasmid. The greater reduction of the worm load induced by the triple antigen vaccine formulation appear to be significant, suggesting that the utilization of multiple antigens in a Schistosoma vaccine can contribute to improve the protective response against this complex pathogen. There was a very low 
humoral response to these DNA vaccines. This seams to be consequence of a low degree of T-helper stimulation. Further studies with the Sm14 and IrV5 antigens targeted to the cellular compartments for major histocompatibility complex class II processing and presentation resulted in an increased T-helper response and markedly greater antibody titers (Ihid C Leão et al. manuscript in preparation). Western blot of soluble and insoluble fractions of worm homogenate probed with a pool of vaccinated sera at the dilution of 1:100 was positive only for the pool from the pIrV5-vaccinated animals (data not shown). The ELISA data suggested that the multivalent vaccines were responsible for raising a specific $\operatorname{IgG}$ response to $S$. mansoni antigen. We are looking to examine the isotype of the $\operatorname{IgG}$ produced by each group tested and study the influence of schedule protocol on the protective response induced by empty vector and on the level of antibody response.

\section{ACKNOWLEDGEMENTS}

To Fabio Melo and Márcio Bezerra for their assistance in maintaning the Schistosoma cycle in the laboratory; to Antônio Diego Falcão and Veruska Lia Fook Alves for their technical help.

\section{REFERENCES}

Arichi T, Saito T, Major ME, Belykov IM, Shirai M, Engelhard VH, Feinstone SM, Berzofsky JA 2000. Prophylactic DNA vaccine for hepatitis $\mathrm{C}$ virus (HCV) infection: HCV-specific cytotoxic $\mathrm{T}$ lymphocyte induction and protection from HCV-recombinant vaccinia infection in na HLA-A2.1 transgenic mouse model. Proc Natl Acad Sci USA 97: 297302.

Chitsulo L, Engels D, Montresor A, Savioli L 2000. The global status of schistosomiasis and its control. Acta Trop 77: 4151.

Chlichlia K, Bahgat M, Ruppel A, Schirrmacher V 2002. DNA vaccination with asparaginyl endopeptidase ( $\mathrm{Sm} 32$ ) from the parasite Schistosoma mansoni: anti-fecundity effect induced in mice. Vaccine 20: 439-447.

Coulson PS 1997. The radiation-attenuated vaccine against schistosomes in animal models: paradigm for a human vaccine? Adv Parasitol 39: 272-323.

Dégano P, Schneider J, Hannan CM, Gilbert SC, Hill AVS 2000. Gene gun intradermal DNA immunization followed by boosting with modified vaccinia virus ankara: enhanced CD8+ T cell immunogenicity and protective efficacy in the influenza and malaria models. Vaccine 18: 623-632.

El-Garen AA 1998. Schistosomiasis. Digestion 59: 589-605.

Grifantini R, Finco O, Bartolini E, Draghi M, Del Giudice G, Kocken C, Thomas A, Abrignani S, Grandi G 1998. Multiplasmid DNA vaccination avoids antigenic competition and enhances immunogenicity of a poorly immunogenic plasmid. Eur J Immunol 28: 1225-1232.

Hota-Mitchell S, Clarke MW, Podesta RB, Dekaban GA 1999. Recombinant vaccinia viruses and gene gun vectors expressing the large subunit of Schistosoma mansoni campain used in a murine immunization-challenge model. Vaccine 17: 13381354.

Johnson PA, Conway MA, Daly J, Nicolson C, Robertson J, Mills KH 2000. Plasmid DNA encoding influenza virus haemagglutinin induces Th1 cells and protection against respiratory infection despite its limited ability to generate antobody responses. J Gen Virol 81: 1737-1745.

Kallina BH 1997. DNA vaccines for parasitic infections. Immunol Cell Biol 75: 370-375.
Lodmell DL, Ray NB, Ewalt LC 1998. Gene gun particle-mediated vaccination with plasmid DNA confers protective immunity against rabies virus infection. Vaccine 16: 115-118.

Mohamed MM, Shalaby KA, LoVerde PT, Karim AM 1998. Characterization of Sm20.8, a member of a family of schistosome tegumental antigens. Mol Biochem Parasitol 96: 15-25.

Morello CS, Cranmer LD, Spector DH 2000. Suppression of murine cytomegalovirus (MCMV) replication with a DNA vaccine encoding MCMV M84 (a homolog of human cytomegalovyrus pp65). J Virol 74: 3696-3708.

Morris S, Kelley C, Howard A, Li Z, Collins F 2000. The immunogenicity of single and combination DNA vaccines against tuberculosis. Vaccine 18: 2155-2163.

Raviprakash K, Porter KR, Kochel TJ, Ewing D, Simmons M, Phillips I, Mrphy GS, Weiss WR, Hayes CG 2000. Dengue virus type 1 DNA vaccine induces protective immune response in rhesus macaques. J Gen Virol 81: 1659-1667.

Sauma SY, Tanaka TM, Strand M 1991. Selective of a glycosylphosphatidylinositol-anchored antigen from the surface of Schistosoma mansoni. Mol Biochem Parasitol 46: 73-80.

Schlereth B, Germann P-G, Meulen VT, Niewiesk S 2000. DNA vaccination with both the haemagglutinin and fusion proteins but not the nucleocapsid protein protects against experimental measles virus infection. J Gen Virol 81: 13211325.

Scott JC, McManus DP 2000. Molecular cloning and enzimatic expression of the 28-kDa glutathione S-transferase of Schistosoma japonicum: evidence for sequence variation but lack of consistent vaccine efficacy in the murine host. Parasitol Int 49: 289-300.

Sin J-I, Kim J, Dang K, Lee D, Patchuk C, Satishchandran C, Weiner DB 2000. LFA-3 plasmid DNA enhances Ag-specific humoral- and cellular-mediated protective immunity against herpes simplex virus-2 in vivo: involvement of CD4+ T cells in protection. Cell Immunol 203: 19-28.

Soisson LM, Masterson CP, Tom TD, McNally MT, Lowell GH, Strand M 1992. Induction of protective immunity in mice using a 62-kDa recombinant fragment of a Schistosoma mansoni surface antigen. J Immunol 149: 3612-3620.

Soisson LM, Reid GD, Farah IO, Nyindo M, Strand M 1993. Protective immunity in baboons vaccinated with a recombinant antigen or radiation-attenuated cercariae of Schistosoma mansoni is antibody-dependent. J Immunol 151: 4782-4789.

Soisson LM, Strand M 1993. Schistosoma mansoni: induction of protective immunity in rats using a recombinant fragment of a parasite surface antigen. Exp Parasitol 77: 492-494.

Tendler M, Brito CA, Vilar MM, Serra-Freire N, Diogo CM, Almeida MS, Delbem AC, Da Silva JF, Savino W, Garratt RC, Katz N, Simpson AS 1996. A Schistosoma mansoni fatty acid-binding protein, $\mathrm{Sm} 14$, is the potential basis of a dual-purpose anti-helminth vaccine. Proc Natl Acad Sci USA 93: 269-273.

Waine GJ, Alarcon JB, Qiu C McManus 1999a. Genetic immunization of mice with DNA encoding the $23 \mathrm{kDa}$ transmembrane surface protein of Schistosoma japonicum $(\mathrm{Sj} 23)$ induces antigen-specific immunoglobulin G antibodies. Parasite Immunol 21: 377-381.

Waine GJ, Mazzer DR, McManus DP 1999b. DNA immunization by intramuscular injection or gene gun induces specific IgG antibodies against a Schistosoma japonicum 22 $\mathrm{kDa}$ antigen, $\mathrm{Sj} 22$, when fused to the murine Ig k-chain secretory leader sequence. Parasite Immunol 21: 53-56.

Waine GJ, Yang W, Scott JC, McManus DP, Kalinna BH 1997. DNA-based vaccination using Schistosoma japonicum (asian blood-fluke) genes. Vaccine 15: 846-848. 
Weissert R, Lobell A, Graaf KL, Eltayeb SY, Andersson R, Olsson T, Wizgel H 2000. Protective DNA vaccination against organ-specific autoimmunity is highly specific and discriminates between single amino acid substitution in the peptide autoantigen. Proc Natl Acad Sci USA 97: 16891694.

Wilson RA, Coulson PS 1998. Why don't we have a schistosomiasis vaccine? Parasitol Today 14: 97-99.

Xiang R, Lode HN, Chao T, Ruehlmann JM, Dolman CS, Rodriguez F, Whitton JL, Overwijk WW, Restifo NP, Reisfeld RA 2000. An autologous oral DNA vaccine protects against murine melanoma. Proc Natl Acad Sci USA 97: 5492-5497.
Ximenes RAA, Southgate B, Smoth PG, Guimarães Neto L 2000. Migration and urban schistosomiasis. The case of São Lourenço da Mata, Northeast of Brazil. Rev Inst Med Trop São Paulo 42: 209-217.

Xu D, McSorley SJ, Chatfield SN, Dougan G, Liew FY 1995. Protection against Leishmania major infection in genetically susceptible BALB/c mice by gp63 delivered orally in attenuated Salmonella typhimurium (AroA- AroD-). Immunology 85: 1-7.

Zhang Y, Taylor MG, Gregoriadis G, McCrossan MV, Bickle QD 2000. Immunogenicity of plasmid DNA encoding the $62 \mathrm{kDa}$ fregment of Schistosoma japonicum myosin. Vaccine 18: 2102-2109. 
